\title{
Hoe populaties personen worden
}

\author{
Citation for published version (APA):
}

Arts, I. C. W. (2014). Hoe populaties personen worden. Maastricht University. https://doi.org/10.26481/spe.20140905ia

Document status and date:

Published: 05/09/2014

DOI:

10.26481/spe.20140905ia

Document Version:

Publisher's PDF, also known as Version of record

\section{Please check the document version of this publication:}

- A submitted manuscript is the version of the article upon submission and before peer-review. There can be important differences between the submitted version and the official published version of record.

People interested in the research are advised to contact the author for the final version of the publication, or visit the DOI to the publisher's website.

- The final author version and the galley proof are versions of the publication after peer review.

- The final published version features the final layout of the paper including the volume, issue and page numbers.

Link to publication

\footnotetext{
General rights rights.

- You may freely distribute the URL identifying the publication in the public portal. please follow below link for the End User Agreement:

www.umlib.nl/taverne-license

Take down policy

If you believe that this document breaches copyright please contact us at:

repository@maastrichtuniversity.nl

providing details and we will investigate your claim.
}

Copyright and moral rights for the publications made accessible in the public portal are retained by the authors and/or other copyright owners and it is a condition of accessing publications that users recognise and abide by the legal requirements associated with these

- Users may download and print one copy of any publication from the public portal for the purpose of private study or research.

- You may not further distribute the material or use it for any profit-making activity or commercial gain

If the publication is distributed under the terms of Article $25 \mathrm{fa}$ of the Dutch Copyright Act, indicated by the "Taverne" license above, 
Prof. Dr. I r. I jja C.W. Arts

Faculty of Health, Medicine and Life Sciences

\section{Hoe populaties personen worden}


Inaugurele rede

Leerstoel 'Moleculaire epidemiologie van chronische ziekten'.

Prof. Dr. Ir. Ilja C.W. Arts

Mijnheer de voorzitter van het College van Bestuur, Leden van het College van Toezicht, geachte collega's, Beste familie, vrienden en andere aanwezigen,

Als ik in gezelschap vertel dat ik epidemioloog ben, is de eerste reactie altijd 'ha nuttig, infectieziekten zijn nog steeds een groot probleem'. Velen associëren epidemiologen met epidemieën, en dat is terecht. Alleen niet álle epidemiologen houden zich daar mee bezig. Als ik vervolgens probeer uit te leggen dat ik me niet met infectieziekten bezig hou, maar met chronische ziekten. En dat ik het ontstaan daarvan beter probeer te begrijpen door gebruik te maken van moleculaire biomarkers, haken de meeste mensen af. Dus het is fijn dat ik vandaag uitgebreid de gelegenheid krijg te vertellen over mijn onderzoeksonderwerp, de moleculaire epidemiologie van chronische ziekten. Ik zal uiteenzetten waarom ik denk dat ook epidemiologisch onderzoek naar chronische ziekten nuttig is, en in welke richting het onderzoeksveld zich naar mijn idee zal begeven.

\section{Epidemiologie}

Maar allereerst, wat is epidemiologie eigenlijk? De epidemiologie is de wetenschap die zich bezig houdt met het vóórkomen van ziekten in populaties en de oorzaken en het beloop van deze ziekten. Epidemiologen onderzoeken dus waarom sommige mensen ziek worden en anderen niet en waarom sommige mensen herstellen van een ziekte en anderen niet. We doen dit door in een populatie te bepalen welke mensen blootgesteld zijn aan een bepaalde factor en kijken vervolgens of deze mensen een verhoogd of juist verlaagd risico op ziekte hebben. Deze kennis kan vervolgens gebruikt worden bij de preventie en de behandeling van ziekten. Het vakgebied vormt daarmee een belangrijke wetenschappelijke pijler voor zowel de volksgezondheidzorg als de geneeskunde. 
John Snow wordt gezien als de 'vader' van de epidemiologie. Deze arts, geboren in 1813 in Engeland, en op deze foto te zien toen hij dezelfde leeftijd had als ik nu, werd wetenschappelijk gegrepen door de cholera epidemieën die in de eerste helft van de $19^{\mathrm{e}}$ eeuw Londen teisterden. Hij was de eerste die op een systematische manier keek naar blootstelling aan een risicofactor, in zijn geval water uit een specifieke waterpomp, in relatie tot een ziekte, cholera. Cholera was in die tijd een dodelijke ziekte waarvan men niet wist wat de oorzaak was, bacteriën waren als ziekteverwekkers nog niet bekend en het heersende idee was dat 'slechte lucht' de ziekte veroorzaakte. John Snow had eerder een hypothese geformuleerd dat de oorzaak van cholera zich in het drinkwater zou bevinden, maar deze hypothese werd niet breed geaccepteerd. $\mathrm{Na}$ een cholera uitbraak in zijn buurt in Londen in augustus 1853, besloot hij data te gaan verzamelen. Hij kreeg een lijst met de namen en adressen van alle sterfgevallen, toen kon dat nog, en markeerde deze op een kaart van Londen. Hier ziet u deze kaart. Vervolgens berekende hij de afstand van het huis van de slachtoffers tot de dichtstbijzijnde openbare waterpomp. 73 van de 83 sterfgevallen bleken te zijn opgetreden in huizen die het dichtst bij de openbare waterpomp op Broad Street lagen. Van de 10 overledenen die dichter bij een andere pomp woonden bleken er 8 toch water uit de Broad Street pomp gedronken te hebben. Een aantal van hen waren bijvoorbeeld kinderen die op weg naar school uit de pomp gedronken hadden. Na deze observationele studie, wist hij de autoriteiten te overtuigen om de hendel van de Broad Street pomp te verwijderen, zodat deze niet meer gebruikt kon worden. Weldra doofde de epidemie uit: een experimentele aanwijzing dat zijn theorie zou kunnen kloppen. Helaas voor John Snow werd zijn theorie pas echt geaccepteerd na zijn dood, toen in 1884 de bacterie Vibrio cholerae werd geïsoleerd. ${ }^{1}$

Dit basisprincipe van epidemiologisch onderzoek, bleek ook prima bruikbaar bij andere ziekten dan infectieziekten. John Snow wist tenslotte niet dat het een infectieziekte was die hij bestudeerde. Epidemiologisch onderzoek is bijvoorbeeld van groot belang geweest bij de ontdekking van de vitamines in de eerste helft van de $20^{\mathrm{e}}$ eeuw. 


\section{Biomarkers}

Wat ik 'traditionele' epidemiologie zou willen noemen, maakt voornamelijk gebruik van relatief eenvoudige observaties of vragenlijsten om blootstelling aan een risicofactor of aanwezigheid van een ziekte te bepalen. Denk hierbij aan afstand tot een waterpomp, lichaamsgewicht, of voedingsgewoonten. De moleculaire epidemiologie maakt daarnaast gebruik van biomarkers. En ik zeg 'daarnaast' omdat ik verwacht dat deze zogenaamd 'traditionele' methoden om blootstellingen en uitkomstmaten te bepalen belangrijk en soms onmisbaar blijven. Denk bijvoorbeeld aan 'kwaliteit van leven'. Dit is een uitkomstmaat die essentieel is in de gezondheidszorg en verwijst naar de subjectieve evaluatie door een persoon van zijn of haar functioneren op fysiek, psychisch en sociaal gebied. Kwaliteit van leven is een subjectief begrip wat onmogelijk anders te meten is dan door het de betreffende persoon te vragen.

Moleculaire epidemiologie maakt dus gebruik van biomarkers. Met een biomarker bedoelen we "... een stof, structuur of proces, gemeten in het menselijk lichaam of de producten daarvan, welke het ontstaan of beloop van een ziekte kan voorspellen of beïnvloeden" ${ }^{2}$. Dit is een brede definitie, die zinvol is omdat hij alles wat objectief meetbaar is in, op of aan het menselijk lichaam omvat. Ook functionele biomarkers zoals bloeddruk en beeldvormende technieken zoals MRI. Ik beperk me in dit kader tot de moleculaire biomarkers: stoffen die we door middel van laboratoriumtechnieken kunnen meten. Moleculaire biomarkers kunnen gebruikt worden om de blootstelling aan een bepaalde omgevings- of leefstijlfactor te meten, om aanwezigheid van ziekte vast te stellen, en om de genetische gevoeligheid voor het krijgen van een ziekte te bepalen. Dit laatste kan ook gezien worden als blootstelling aan genetische factoren. Moleculaire biomarkers kunnen in een groot scala aan lichaamsmaterialen gemeten worden. In ons onderwijs gebruiken we vaak high-tech methoden om studenten hierover te laten brainstormen, zoals de door Dr. Roger Godschalk bedachte BioBob. In de praktijk van het epidemiologisch onderzoek zijn we echter vaak beperkt tot bloed, urine, of ontlasting, materialen die op een relatief eenvoudige manier bij grote aantallen mensen af te nemen zijn. 
Met behulp van biomarkers kunnen we vaak preciezer in kaart brengen waaraan mensen zijn blootgesteld en of ze ziek zijn. Dit wordt weergegeven in dit model, gebaseerd op werk van Prof. Paolo Vineis. Ik wil graag een voorbeeld hiervan geven uit mijn eigen onderzoek. Naast eiwit, vet, koolhydraten, vitamines en mineralen bevat onze voeding ook een groot aantal andere stoffen, die niet essentieel lijken te zijn, maar wel een effect hebben op het menselijk lichaam, de bioactieve stoffen. Voorbeelden van dit soort stoffen zijn de flavonoïden, die voorkomen in thee, rode wijn en chocolade. ${ }^{3}$ Een ander voorbeeld zijn de lignanen, onderwerp van het promotieonderzoek van Anneleen Kuijsten en Ivon Milder. Dit is destijds onder leiding van Dr. Peter Hollman in Wageningen uitgevoerd. Lignanen komen voor in plantaardige voedingsmiddelen zoals brood, broccoli en thee. ${ }^{4}$ De blootstelling aan lignanen is vast te stellen via vragenlijsten, dit reflecteert de 'externe blootstelling': dat wat het lichaam in gaat. De lignanen zelf blijken echter nauwelijks door het lichaam opgenomen te worden. Ze passeren de maag en dunne darm en gaan door naar de dikke darm waar ze door darmbacteriën omgezet worden in andere stoffen, de zogenaamde enterolignanen. Deze enterolignanen worden wel opgenomen en zijn terug te vinden in het bloed. ${ }^{5}$ Enterolignaan concentraties in bloed reflecteren de 'interne blootstelling'.

Behalve om blootstelling en ziekte preciezer in kaart te brengen, kunnen moleculaire biomarkers ook gebruikt worden om beter te begrijpen welke biologische mechanismen ten grondslag liggen aan de relatie tussen een blootstelling en een ziekte. Dus waarom een bepaalde blootstelling tot ziekte leidt. Dit soort informatie is nuttig omdat het enerzijds nieuwe aanknopingspunten oplevert voor de preventie en behandeling van ziekten. En anderzijds ons helpt om met grotere betrouwbaarheid, in een vroeger stadium een ziekte te diagnosticeren en het beloop te voorspellen. In de 'traditionele' epidemiologie is het onderliggende mechanisme vaak een 'black box': we weten niet waarom een bepaalde blootstelling en uitkomstmaat aan elkaar gerelateerd zijn. Door gebruik te maken van biologische kennis over het ontstaan van ziekten en door inzet van biologische markers die iets zeggen over deze processen, wordt de 'black box' steeds transparanter. Elisabeth Hertle, bijvoorbeeld, doet promotieonderzoek naar de rol van het complement systeem bij hart- en vaatziekten. Zij doet dit onder begeleiding van Dr. Marleen 
van Greevenbroek, Prof. Coen Stehouwer en mijzelf. Het complement systeem is onderdeel van ons immuunsysteem en er zijn aanwijzingen dat activatie van het complement systeem het risico op hart- en vaatziekten verhoogt. Elisabeth liet zien dat complement factoren C5a en C5b-9 wel geassocieerd zijn met chronische ontsteking en endotheel dysfunctie, maar niet met atherosclerose, allen biologische processen die van belang zijn bij het ontstaan van hart- en vaatziekten. ${ }^{6}$

\section{Chronische ziekten}

Moleculaire epidemiologie levert een zinvolle bijdrage aan het beter begrijpen van vrijwel alle ziekten, maar ik beperk mij in mijn onderzoek tot chronische ziekten, in het bijzonder overgewicht en obesitas, type 2 diabetes mellitus, en hart- en vaatziekten.

Zuid-Limburg heeft een relatief hoge prevalentie van overgewicht en obesitas ${ }^{7}$. De Body Mass Index, BMI, is een breed geaccepteerde maat om te bepalen of iemand overgewicht heeft. De BMI wordt berekend door het gewicht van iemand te delen door het kwadraat van zijn lengte in meters. Een BMI van 25 of meer betekent dat iemand overgewicht heeft. Een BMI van 30 of meer betekent dat iemand obesitas heeft. Het percentage Nederlanders met overgewicht is de afgelopen 30 jaar sterk gestegen en inmiddels heeft ongeveer de helft van alle Nederlanders te kampen met overgewicht, in ZuidLimburg is dat zelfs bijna $52 \%$. Maar het is zeker niet alleen een regionaal probleem, zoals dit bericht lijkt te suggereren. Volgens huidige voorspellingen zullen er in het jaar 2030 wereldwijd meer dan een miljard mensen met overgewicht zijn. $^{8}$

Diabetes, ofwel suikerziekte, is na artrose de meest voorkomende ziekte in Nederland. Op 1 januari 2011 waren er meer dan 830.000 mensen met diabetes bekend bij de huisarts, ongeveer evenveel mannen als vrouwen. De prevalentie is het hoogst bij mensen tussen de 75 en 85 jaar. Van alle patiënten met diabetes heeft $90 \%$ type 2 diabetes. Dit is de vorm van diabetes die vroeger 'ouderdomsdiabetes' genoemd werd, maar tegenwoordig op steeds jongere leeftijd voorkomt. Zelfs bij kinderen wordt tegenwoordig type 2 diabetes gevonden. We weten daarnaast dat een deel van de mensen met 
diabetes niet bekend is bij de huisarts. Het totale aantal mensen met diabetes ligt dus nog hoger. De meest recente schattingen zijn dat ongeveer $25 \%$ van de mensen met diabetes nog niet gediagnosticeerd is. Dit is een probleem omdat bij veel mensen schade aan bijvoorbeeld de bloedvaten al opgetreden is op het moment van diagnose. Vroege opsporing is dus van belang. ${ }^{9}$

Hart- en vaatziekten is een verzamelnaam voor een groot aantal aandoeningen van het hart en de bloedvaten. Coronaire hartziekten komen het meest voor, gevolgd door cerebrovasculaire aandoeningen, ofwel beroertes. Zij vormen samen meer dan de helft van het totaal aantal hart- en vaatziekten. Per jaar worden ruim 280.000 mensen opgenomen in een ziekenhuis vanwege hart- en vaatziekten. Dankzij betere behandeling overlijden er steeds minder mensen aan hart- en vaatziekten, maar de prevalentie neemt wel nog steeds toe. Harten vaatziekten zijn bovendien nog steeds de tweede meest voorkomende doodsoorzaak in Nederland, net na kanker. In 2011 stierven in Nederland meer dan 38.000 personen aan een hart- en vaatziekte, meer dan 100 per dag. ${ }^{9}$

Biologisch gezien zit er grote overlap in de mechanismen die een rol spelen bij het ontstaan van obesitas, type 2 diabetes en hart- en vaatziekten. Bij al deze aandoeningen spelen bijvoorbeeld chronische ontstekingen een rol. ${ }^{10}$ Maar toch krijgt niet iedereen met obesitas diabetes en zijn niet alle diabeten obees. Hetzelfde geldt voor hart- en vaatziekten. De uitdaging zit er in beter te begrijpen welke biologische mechanismen er voor zorgen dat de ene persoon met obesitas gezond blijft, de ander diabetes krijgt, en een derde zowel diabetes als hart- en vaatziekten. Belangrijk daarbij is veel preciezer in kaart te brengen hoe het ziektebeeld van een individu er uit ziet en welke biologische mechanismen ontregeld zijn. De ene chronische ontsteking is de andere niet.

Voor de uitvoering van mijn onderzoek ben ik in de gelukkige omstandigheid dat ik gebruik kan maken van prospectieve cohorten die in het verleden door collega's van de Universiteit Maastricht zijn opgezet. Epidemiologische studies zijn een soort ultramarathons. Hoe langer ze duren, hoe hoger de wetenschappelijke opbrengst. Het vergt dan ook zeer veel visie, doorzettingsvermogen en investeringen om deze studies op te zetten en te onderhouden. Dankzij de visionaire inzichten en het harde werk van de 
volgende collega's kan ik mijn onderzoek, samen met hen, uitvoeren: Dr. Carel Thijs, Dr. Monique Mommers, Dr. John Penders en Prof. Pieter Dagnelie van het KOALA Geboortecohort, en Prof. Coen Stehouwer, Dr. Miranda Schram, Dr. Carla van der Kallen, en Dr. Marleen van Greevenbroek van de cohorten CODAM en De Maastricht Studie.

\section{Grenzen aan de reductionistische epidemiologie}

Hoewel het onderzoek wat ik tot nu toe beschreven heb moleculaire biomarkers gebruikt, is het in veel opzichten nog 'traditioneel' te noemen. We proberen zo precies en valide mogelijk het effect van één blootstelling op één uitkomstmaat vast te stellen. En we houden daarbij rekening met andere blootstellingen die ook een effect op de uitkomstmaat hebben, zogenaamde confounders. We gebruiken wiskundige technieken om het effect waarin we geïnteresseerd zijn te corrigeren voor de effecten van deze confounders. Deze reductionistische benadering, die ik zelf veel en succesvol gebruikt heb, begint naar mijn mening zijn grenzen te bereiken. Ik wil hierbij twee ontwikkelingen schetsen die daar sterk van invloed op zijn.

Allereerst kennen we inmiddels voor de meeste ziekten de belangrijkste risicofactoren. Denk bijvoorbeeld aan overgewicht, cholesterol, en bloeddruk voor hart- en vaatziekten. Deze factoren hebben een groot effect op het risico op ziekte. Toch kunnen we in lang niet alle gevallen correct voorspellen of iemand daadwerkelijk hart- en vaatziekten krijgt. Er zijn blijkbaar nog andere factoren die dit risico beïnvloeden, die we nog niet kennen. Deze factoren hebben vaak een kleiner effect, of hebben alleen een effect wanneer ze samen met andere factoren voorkomen. Dit laatste noemen we interactie. We zien in de praktijk dat veel chronische ziekten erg complex zijn: er zijn een groot aantal factoren die mede bepalen of iemand uiteindelijk ziek wordt of niet, veel van deze factoren hebben maar een klein effect, en het effect van de meeste factoren is bovendien afhankelijk van de aanwezigheid van andere factoren.

Ik wil dit graag illustreren aan de hand van een voorbeeld uit het promotieonderzoek van José Wijnands. José is geïnteresseerd in de relatie tussen urinezuur en hart- en vaatziekten. Urinezuur wordt door het lichaam zelf geproduceerd als afbraakproduct van onder andere DNA, en ATP, de 
energieleverancier van het lichaam. Urinezuur is vooral bekend omdat het kan leiden tot jicht wanneer de concentraties in het bloed te hoog oplopen. Al jaren wordt echter gedacht dat urinezuur ook het risico op hart- en vaatziekten kan verhogen. In haar onderzoek heeft José met behulp van data uit CODAM en De Maastricht Studie gekeken naar de relatie tussen de concentratie urinezuur in bloed (als blootstelling) en verschillende vroege indicatoren voor hart- en vaatziekten (als uitkomstmaten). Aangemoedigd door haar begeleidingsteam, Prof. Annelies Boonen, Prof. Coen Stehouwer en mijzelf heeft José getracht alle andere factoren die deze relatie beïnvloeden in een figuur weer te geven. Alleen door voor deze factoren te corrigeren kunnen we immers het onafhankelijke effect van urinezuur op hart- en vaatziekten bepalen. Deze figuur geeft haar poging weer en is helaas nog een sterk versimpelde versie van de werkelijkheid. Wat u direct op zal vallen is dat het veel factoren zijn en dat de relaties complex zijn. Hypertensie wordt bijvoorbeeld gezien als een belangrijke risicofactor voor hart- en vaatziekten, waarvoor we moeten corrigeren als we het onafhankelijke effect van urinezuur willen bepalen. Sommige factoren zijn echter niet alleen confounder, maar zitten ook in de causale keten van urinezuur naar hart- en vaatziekten. Zo kan een hoge concentratie urinezuur via oxidatieve stress of via endotheel dysfunctie de oorzaak zijn van hypertensie. Met de wiskundige modellen die binnen de reductionistische benadering van de epidemiologie gebruikt worden, onderschatten we het onafhankelijke effect van urinezuur wanneer we corrigeren voor factoren die in de causale keten zitten. Als we echter niet corrigeren voor hypertensie overschatten we het werkelijke effect. Om te begrijpen hoe de verschillende risicofactoren elkaar beïnvloeden en uiteindelijk wel of niet tot ziekte leiden zullen we een meer holistische benadering van de epidemiologie en andere manieren van data-analyse moeten gebruiken.

\section{De opkomst van omics}

Een tweede belangrijke ontwikkeling die het veld van de moleculaire epidemiologie een enorme impuls aan het geven is, zijn technologische ontwikkelingen in het laboratorium, waardoor moleculaire biomarkers steeds beter, sneller en goedkoper gemeten kunnen worden. Hierdoor wordt het mogelijk veel biomarkers tegelijkertijd te meten bij een groot aantal personen. Ter illustratie: toen in het jaar 2003 de eerste versie van het humane genoom 
beschikbaar kwam had het 13 jaar geduurd en 3 miljard dollar gekost om de DNA volgorde van 4 mensen in kaart te brengen. ${ }^{11}$ Tegenwoordig krijg je vergelijkbare informatie binnen een paar dagen nadat je via internet een kitje besteld hebt voor 99 dollar. Hoewel het ontrafelen van het humane genoom een groot aantal genen heeft opgeleverd die potentieel het risico op ziekte verhogen, is de winst in termen van gezondheid tot nu toe beperkt. Een van de oorzaken daarvan is dat genen in potentie een effect kunnen hebben, maar dat andere genetische en omgevingsfactoren meestal bepalen of die potentie ook daadwerkelijk tot uitdrukking komt. Zie hier mijn nichtjes Wies en Aafje, genetisch identiek, maar zeker niet hetzelfde. En denk in de context van gezondheid en ziekte bijvoorbeeld aan phenylketonurie, PKU. PKU is een ziekte waarbij het gen voor de afbraak van het aminozuur phenylalanine niet goed functioneert. Op deze aandoening worden pasgeboren baby's via de hielprik gecontroleerd. Als je het defecte gen hebt, kun je in potentie de ziekte krijgen. Maar je krijgt hem alleen wanneer je via de voeding het aminozuur phenylalanine ook daadwerkelijk binnenkrijgt. Met een phenylalanine-arm dieet voorkom je de ziekte. Er is dus een omgevingsfactor nodig om het effect van het gen tot uitdrukking te laten komen.

Hoe komen we nu precies van genotype, de verzameling genetische informatie die is geërfd van de ouders, naar fenotype, de verzameling waarneembare eigenschappen van een individu? De genen, die bestaan uit DNA, worden eerst omgezet in RNA. RNA lijkt qua chemische structuur sterk op DNA, maar het bestaat doorgaans maar uit een enkele streng nucleotiden. Via RNA kunnen snel grote aantallen kopieën gemaakt worden van de genetische informatie die in het DNA opgeslagen is. Dit proces noemen we transcriptie. Het RNA wordt vervolgens via translatie omgezet in eiwit. Eiwitten bestaan uit ketens van aminozuren en kunnen zeer complexe 3D-structuren aannemen. Eiwitten zijn de werkelijk functionele moleculen van het lichaam. In het geval van PKU werkt het eiwit phenylalaninehydroxylase niet goed. Eiwitten voeren reacties uit waarbij kleine moleculen omgezet worden in andere kleine moleculen, zogenaamde metabolieten. Het eiwit phenylalaninehydroxylase zet phenylalanine om in zijn metaboliet tyrosine. Al deze processen worden gereguleerd, onder andere via epigenetische modificaties van het DNA, bijv. methylering en histone acetylering, via microRNA's die de stabiliteit en 
translatie van RNA beïnvloeden, en via gerichte afbraak van eiwitten. Van al deze soorten moleculen kunnen we in toenemende mate de volledige set meten, dus bijvoorbeeld alle variaties in alle genen, of alle metabolieten in het bloed. In het geval van de genen spreken we dan over het genoom, van RNA over het transcriptoom, van eiwitten over het proteoom, van alle kleine circulerende moleculen over het metaboloom, enzovoort. En het beperkt zich niet tot humane moleculen. Samen met Dr. John Penders en BGI in China en in het kader van het promotieonderzoek van Catherine Akwi Mbakwa met Prof. Hauke Smidt van Wageningen Universiteit, meten we ook de samenstelling van onze darmflora, de micro-organismen die zich in onze darmen bevinden, inderdaad, het microbioom. Het wordt steeds duidelijker dat ook het microbioom onze gezondheid op allerlei manieren beïnvloedt.

Al deze metingen geven een enorme schat aan data, maar om hier ook daadwerkelijk nuttige informatie uit te halen, die ons helpt bij het beter begrijpen, voorspellen, voorkómen en genezen van chronische ziekten is een grote uitdaging.

\section{Systeembiologie als oplossingsrichting}

Ik denk dat een systeembiologische aanpak van de moleculaire epidemiologie een oplossing kan bieden voor de zojuist geschetste uitdagingen. Ik ben er dan ook heel gelukkig mee dat de Universiteit Maastricht, ondersteund door de provincie Limburg, dit jaar besloten heeft het interfacultaire Maastricht Centre for Systems Biology (MaCSBio) op te richten. Met gepaste trots mag u bij deze de kersverse website van het centrum laten zien. Het is de bedoeling dat MaCSBio een kristallisatiekern wordt voor onderzoek en onderwijs op het gebied van de systeembiologie, met input vanuit de drie betrokken faculteiten Health, Medicine and Life Sciences (FHML), Humanities and Sciences (FHS) en Psychology and Neuroscience (FPN). Samen met Dr. Theo de Kok, leid ik een van de twee onderzoekslijnen binnen dit centrum. Ons onderzoek zal zich richten op het ontstaan van chronische ziekten, inclusief kanker, bij mensen met obesitas. We zullen hiertoe ook Euregionale samenwerkingsverbanden aangaan met de universiteiten van Eindhoven, Luxemburg, Luik en Hasselt. Dat systeembiologie een interdisciplinaire tak van wetenschap is, moge duidelijk 
worden wanneer ik de bij deze onderzoekslijn betrokken wetenschappers laat zien.

Maar wat is systeembiologie en waarom denk ik dat de moleculaire epidemiologie daar een zinvolle bijdrage aan kan leveren? Er is geen breed geaccepteerde definitie van systeembiologie en ik ga me daar hier ook niet aan wagen. In essentie is het doel van systeembiologie een biologisch systeem, bijvoorbeeld een mens, beter te begrijpen door het in zijn geheel te bestuderen. Onderzoekers hebben verschillende ideeën over hoe dit doel bereikt kan worden en de verschillende definities reflecteren deze ideeën. Verder kenmerkt de systeembiologie zich door een nauwe band tussen diegenen die de biologische data genereren en diegenen die hier berekeningen op los laten. Binnen onze onderzoekslijn gaan we uit van een meer top-down systeembiologische benadering, waarbij we verschillende typen data afkomstig uit onze epidemiologische studies integreren. Het gaat dan om verschillende soorten omics data, maar ook om informatie over leefstijl en ziektestatus van de deelnemers. Het soort onderzoek wat wij beogen is pas sinds kort mogelijk door de eerder geschetste technologische ontwikkelingen in het laboratorium. De Maastricht Studie bijvoorbeeld, bestaat op dit moment uit bijna 6000 deelnemers en het was enkele jaren geleden uitgesloten dat we van al deze deelnemers het metaboloom zouden bepalen. Momenteel worden deze metingen met subsidies van BBMRI en het Maastricht UMC+ verricht.

Een belangrijke mijlpaal waarvan we in onze onderzoekslijn gebruik gaan maken is de publicatie in 2013 van Recon $2^{12}$. Recon 2 is eerder door co-auteur Prof. Hans Westerhoff vergeleken met een wegenkaart van het menselijk lichaam, een soort Google Maps. Het bevat informatie over bijna 7500 reacties die door eiwitten gekatalyseerd worden en waarbij metabolieten gevormd worden. Het laat ook zien hoe al deze reacties met elkaar samenhangen in een netwerk. Samen met Prof. Ines Thiele van het Luxembourg Centre for Systems Biomedicine, de eerste auteur van de Recon 2 publicatie, en met collega Prof. Chris Evelo gaan we de komende jaren deze 'wegenkaart' verder invullen met regulatoire informatie zoals RNA en microRNA's. Om in de analogie met Google Maps te blijven: waar staan de verkeerslichten, wat zijn de snelwegen, en welke alternatieve routes zijn er bij een file. Ook gaan we deze kaart zo 
aanpassen dat hij het lichaam van een persoon met obesitas weergeeft. Door de data van deelnemers aan onze epidemiologische cohorten op deze 'wegenkaart' te projecteren, zijn we in staat beter te begrijpen waardoor sommige deelnemers ziek worden en anderen niet.

We weten steeds meer van de personen in onze populaties

Doordat we steeds meer meten, bestaan onze epidemiologische studies steeds minder uit populaties en meer uit series personen. Het zijn niet langer stipjes op een kaart van Londen, maar individuen waarvan we veel weten, niet alleen op een bepaald moment, maar vaak ook over een bepaalde tijdsperiode.

Een interessante ontwikkeling in dit kader is de 'quantified self' beweging. Ik citeer van hun website: "Steeds meer mensen doen aan 'selftracking'; ze houden dagelijks bij hoeveel ze bewegen, wat ze eten, wat hun hartslag en bloeddruk is, hoe laat ze naar bed gaan, hoe vaak ze de hond uitlaten of hoeveel luiers ze verwisselen. Omdat het kan, omdat het leuk is en omdat het inzicht oplevert om op basis hiervan betere beslissingen te kunnen nemen." ${ }^{13}$ Er zijn steeds meer apps en gadgets op de markt om je eigen gezondheidstoestand te monitoren. Zelfs de Universiteit Maastricht doet daar aan mee via de 'Burn fat not fuel' actie. Medewerkers kunnen met een app bepalen hoeveel calorieën zij verbranden tijdens de fietstocht van huis naar werk. De wetenschapper Michael Snyder toonde aan dat dit ook wetenschappelijk interessante informatie op kan leveren door zichzelf intensief te monitoren gedurende een periode van 14 maanden. ${ }^{14} \mathrm{Hij}$ liet daarbij bijvoorbeeld zien dat een beginnende verstoring van het glucosemetabolisme, hier weergegeven door de zwarte stijgende lijn, door leefstijlverandering teruggedrongen kon worden. Snyder was gedurende zijn onderzoek natuurlijk zeer gemotiveerd en werd niet gehinderd door geldgebrek. Hierdoor zijn de data die hij verzamelde waarschijnlijk valide en reproduceerbaar. Een recent zeer interessant initiatief van Dr. Ben van Ommen en NUGO om een cohort te vormen op basis van zelfmonitoring, het Nutrition Researcher Cohort ${ }^{15}$ worstelt vooralsnog met een aantal van dit soort problemen.

Interdisciplinair samenwerken is noodzakelijk (en leuk)! 
Het mag $u$ inmiddels duidelijk zijn dat de moleculaire epidemiologie een interdisciplinaire aanpak vergt. Hoewel sommige disciplines al een enorme ontwikkeling hebben doorgemaakt, waar de moleculaire epidemiologie van profiteert, liggen er nog grote uitdagingen. Een van die grote uitdagingen is hoe om te gaan met de hoeveelheid data die we genereren. Hoe kunnen we de data toegankelijk, georganiseerd en begrijpelijk maken? Maar ook: hoe kunnen we de data reduceren, voldoende rekening houden met eventuele vertekening, en de complexe relaties en interacties optimaal modelleren? Dit vereist een verdere ontwikkeling van de moleculaire epidemiologie in samenwerking met onder andere de bioinformatica en de biostatistiek. De moleculaire epidemiologie zal innovatieve onderzoeksdesigns en analysemethoden moeten ontwikkelen om de kracht van omics gedreven studies en de kracht van traditionele epidemiologische studies nader bij elkaar te brengen.

Gelukkig kan ik hierin optrekken met mijn collega Prof. Matty Weijenberg, hoogleraar moleculaire epidemiologie van kanker, en medeoprichter van M2E2, de Maastricht Molecular Epidemiology Expertise group. In de afgelopen jaren hebben wij naast onze focus op onderzoek, de moleculaire epidemiologie meer verweven in het onderwijs van de faculteit Health, Medicine and Life Sciences. In de toekomst zullen we dit ook gaan doen in de Master Systeembiologie. Daarnaast hebben we dit jaar voor de derde keer een internationale postdoctorale cursus moleculaire epidemiologie georganiseerd. Deze cursus is mede dankzij de inbreng van vele collega's uit aanpalende vakgebieden een groot succes, maar vooral ook heel erg leuk om te doen! Dat laatste wil ik graag benadrukken: interdisciplinair samenwerken is niet altijd gemakkelijk maar wel bijna altijd heel erg leuk. Zelf heb ik me altijd al moeilijk kunnen beperken tot één discipline. Ik ben daarom ook erg blij dat er voor interdisciplinair onderzoek steeds meer aandacht komt.

\section{Personalized health}

Tot nu toe heb ik steeds over onderzoek en onderwijs gepraat, maar uiteindelijk gaat het natuurlijk om de patiënt, of de aankomende patiënt, de persoon. Ik heb dan ook heel blij dat we dit jaar een subsidie hebben mogen ontvangen van Maastricht UMC+ in het kader van het Strategisch Plan Maastricht UMC+ 2020. De focus hiervan is innovatief, internationaal 
onderscheidend, multidisciplinair onderzoek met een regionaal perspectief vanuit het motto 'Healthy Living'. Het onderzoek wat we in dit kader gaan doen is complementair aan wat we binnen de systeembiologie gaan doen en vooral gericht op toepassing van de opgedane kennis in de klinische praktijk. Integratie van de metabole kennis aanwezig bij NUTRIM en de cardiovasculaire kennis bij CARIM is hiervoor essentieel. Dit is gewaarborgd door de betrokkenheid van onder andere Prof. Ellen Blaak en Prof. Coen Stehouwer.

In de kliniek is er een toenemende behoefte om de preventie, diagnose, behandeling en prognose van ziekten te verbeteren door deze toe te spitsen op steeds specifiekere subgroepen van de bevolking, de zogenaamde personalized health benadering. Daarbij wil ik benadrukken dat niet alleen de behandeling van chronische ziekten meer op maat moet worden, maar dat ook preventiemaatregelen en leefstijladviezen op de persoon afgestemd moeten worden. Gewichtsverlies leidt bijvoorbeeld niet bij iedereen tot een verbetering van het cardiometabool risicoprofiel en daar lijkt een biologische basis voor te zijn. ${ }^{16}$ Daarom spreek ik liever over personalized health dan personalized medicine. Of preventie en behandeling ooit echt personalized zullen worden, durf ik niet te voorspellen. Maar er is al ontzettend veel gezondheidswinst te behalen wanneer we in staat zijn patiënten te classificeren in kleinere, meer homogene subgroepen. Op het gebied van kanker zijn hier al stappen gemaakt, denk bijvoorbeeld aan de antihormonale therapie van hormoongevoelige borstkankers.

En hiermee wil ik terug gaan naar John Snow: er waren ongetwijfeld ook mensen die van de pomp dronken en niet overleden. Net zoals er mensen zijn die hun hele leven roken en geen longkanker krijgen, en er mensen zijn die veel te dik en toch fit zijn. 'Dé mens bestaat niet': op biologisch niveau zijn er weliswaar grote overeenkomsten tussen mensen, maar er zijn ook grote verschillen. En die verschillen bepalen uiteindelijk of een persoon ziek wordt. Wanneer we willen voorspellen wie er gezond blijft en hoe we dat kunnen beïnvloeden zullen we de onderliggende biologie beter moeten begrijpen. We moeten naar 'biology-based prediction'.

\section{Dankwoord}


Ik hoop dat ik vandaag duidelijk heb kunnen maken waar mijn moleculair epidemiologisch pad heen gaat: weg van de reductionistische, traditionele epidemiologie, naar een holistische, systeembiologische aanpak van de epidemiologie. De richting is duidelijk, waar het pad precies uit komt is dat nog niet, en daar hou ik wel van. Verder kunt $u$ zien dat het een prachtig pad is, maar zeker geen snelweg, er zullen nog de nodige hobbels genomen moeten worden.

Mijn pad tot dusverre liep grofweg van Haps, via Wageningen en Bilthoven naar Maastricht. Van de populatie 'mensen die Ilja Arts kennen' wil ik graag een aantal personen in het bijzonder noemen. Ik begin bij het voorlopig eindpunt, Maastricht.

Allereerst wil ik het College van Bestuur van de Universiteit Maastricht danken voor het instellen van deze bijzondere leerstoel. In het bijzonder wil ik hierbij collegevoorzitter Prof. Martin Paul noemen die als decaan van FHML het Toptalent Programma geïnitieerd heeft. Binnen dit programma worden periodiek talenten gescout en begeleid op hun pad tot hoogleraar. Ik heb hier ontzettend veel van geleerd en het heeft bovendien een geweldig clubje collega-hoogleraren en hoogleraren-in-wording opgeleverd. Dames, ik weet niet zeker of ik de lunch maandag haal!

Daarnaast bedank ik mijn College van Toezicht en andere hoogleraren die mijn benoeming mogelijk gemaakt hebben: professoren Albert Scherpbier, Nanne de Vries, Martin Prins, Frits van Merode, Onno van Schayck, Thomas Unger, Pieter Dagnelie en Coen Stehouwer. Ik ben dankbaar dat ik als interdisciplinair onderzoeker een plek heb gevonden bij verschillende onderzoeksscholen en centra: CAPHRI School for Public Health and Primary Care, CARIM School for Cardiovascular Diseases, en MaCSBio Maastricht Centre for Systems Biology. Interdisciplinair onderzoek houdt zich niet aan hokjes. Ik hoop dat mijn wervend vermogen dat ook niet hoeft te doen...

Ik voel me erg op mijn plek bij de vakgroep Epidemiologie, ook al ben ik dan een 'rare' epidemioloog. Hele fijne collega's, goede discussies, gezellige lunches, kanotochten in ondiep water, en af en toe een 'koffiemomentje'. Een speciale 
vernoeming is voor Bas Verhage, die ook aan mijn presentatie vandaag een bijdrage heeft geleverd. Alle mooie plaatjes waren van hem.

Promovendi en studenten begeleiden is eigenlijk het leukste onderdeel van het werk. Dank daarom voor al jullie enthousiasme, ideeën en leergierigheid.

Mijn eigen promotie en postdoctoraal onderzoek heb ik verricht op het RIKILT in Wageningen bij Dr. Peter Hollman en Prof. Jaap Keijer, en op het RIVM in Bilthoven bij Prof. Daan Kromhout en Prof. Edith Feskens. Bij jullie is mijn spagaat tussen lab en epidemiologie begonnen. Wat ben ik jullie dankbaar dat jullie een dergelijk project bedacht hadden, en er bovendien vertrouwen in hadden dat ik, die nog nooit in het lab had gestaan, dat wel aan kon. Ik heb ontzettend veel geleerd van jullie allemaal, en van ieder van jullie weer iets anders.

Tijdens mijn verblijf in Bilthoven heb ik nog een uitstapje gemaakt naar Minneapolis, waar ik met Prof. David Jacobs Jr. samen achter de computer zat. Ik probeer zijn voorbeeld te volgen bij mijn studenten. Edith, je vertelde me ooit dat jij en David Jacobs bij mijn promotie tegen elkaar hadden gezegd "she's gonna make a fine professor some day". Nou, professor ben ik nu, ik hoop dat het ook 'fine' wordt.

Vrienden en familie zijn uiteindelijk het belangrijkst en ik ben dankbaar dat ik die langs al mijn paden gevonden en behouden heb. Jullie waren er door dik en dun. Pap en mam, zonder jullie had ik hier niet gestaan en dat heeft zowel genetische als omgevingsgerelateerde oorzaken. Jullie hebben me altijd gestimuleerd en vonden het vanzelfsprekend dat ik uit Haps weg ging om te studeren. Ik weet niet of jullie ooit gedacht hadden dat je nu hier zou zitten.... Super dat jullie er zijn!

Ik heb gezegd. 


\section{Referenties}

1. http://www.ph.ucla.edu/epi/snow.html.

2. Workshop report. Application of biomarkers in cancer epidemiology. In: Toniolo P, ed. Application of biomarkers in cancer epidemiology. Lyon: IARC Scientific Publications, 1997 (E-reader).

3. Arts ICW, Hollman PCH, Kromhout D. Chocolate as a source of tea flavonoids. Lancet 1999;354:488.

4. Milder IEJ, Arts ICW, van de Putte B, Venema DP, Hollman PCH. Lignan contents of Dutch plant foods: a database including lariciresinol, pinoresinol, secoisolariciresinol and matairesinol. Br J Nutr 2005;93:393402.

5. Kuijsten A, Arts ICW, Vree TB, Hollman PCH. Pharmacokinetics of enterolignans in healthy men and women consuming a single dose of secoisolariciresinol diglucoside. J Nutr 2005;135:795-801.

6. Hertle $\mathrm{E}$, van Greevenbroek MM, Arts ICW, et al. Complement activation products $\mathrm{C} 5 \mathrm{a}$ and $\mathrm{s} \mathrm{C} 5 \mathrm{~b}-9$ are associated with low-grade inflammation and endothelial dysfunction, but not with atherosclerosis in a crosssectional analysis: the CODAM study. Int J Cardiol 2014;174:400-3.

7. http://www.zorgatlas.nl/beinvloedende-factoren/lichamelijkeeigenschappen/.

8. Kelly T, Yang W, Chen CS, Reynolds K, He J. Global burden of obesity in 2005 and projections to 2030. Int J Obes 2008;32:1431-7.

9. http://www.nationaalkompas.nl/gezondheid-en-ziekte/ziekten-enaandoeningen/.

10. Rocha VZ, Libby P. Obesity, inflammation, and atherosclerosis. Nature reviews Cardiology 2009;6:399-409.

11. http://www.genome.gov/10001772.

12. Thiele I, Swainston N, Fleming RM, et al. A community-driven global reconstruction of human metabolism. Nat Biotechnol 2013;31:419-25.

13. http://www.quantifiedself.nl/.

14. Chen R, Mias GI, Li-Pook-Than J, et al. Personal omics profiling reveals dynamic molecular and medical phenotypes. Cell 2012;148:1293-307.

15. van Ommen B. The nutrition researcher cohort: toward a new generation of nutrition research and health optimization. Genes \& nutrition 2013;8:343-4.

16. Phillips CM. Metabolically healthy obesity: definitions, determinants and clinical implications. Rev Endocr Metab Disord 2013;14:219-27. 